\title{
From Altar to Forests: Chinese Ancient Wine's Cultural Functions
}

\author{
Hongliang $\mathrm{Du}^{1}$ \\ ${ }^{1}$ Foreign Language Department, Zhengzhou University of Light Industry, China \\ Correspondence: Hongliang Du, Zhengzhou University of Light Industry, 5 Dongfeng Road, Jinshui District, \\ Zhengzhou 450002, China. Tel: 86-371-6355-6620. E-mail: duhl1971@126.com
}

\author{
Received: December 12, $2011 \quad$ Accepted: February 29, $2012 \quad$ Published: July 1, 2012 \\ doi:10.5539/ach.v4n2p118 \\ URL: http://dx.doi.org/10.5539/ach.v4n2p118
}

This research is financed by Ministry of Education of the People's Public of China (11YJA751011).

\begin{abstract}
With a profound cultural crystalization, China was one of the first countries to brew wine in the world. As a Cultural carrier, wine ever performed the functions of religion, literature, art, and entertainment. To have a deep understanding of Chinese extensive and profound culture, it is necessary to pore over Chinese ancient wine's various functions.
\end{abstract}

Keywords: altar, forest, ancient wine, cultural function

\section{Introduction}

It seems that Chinese cultural history has been written in wine. With the rolling out of the srcroll of Chinese national art, intense vinous flavour comes out from between the lines. For those who want to have a good standing of Chinese extensive and profound culture, it is a useful way to probe into the origins and functions of ancient wine, and it is also very necessary to know about the various forms of elegant tastes concerning ancient wine.

\section{Origin of Wine}

China was one of the first countries to brew wine in the world. As for the time of wine's invention, there are various legends. The most popular one is that Du Kang was the inventor, but there is no evidence. In legend, Du Kang once put cooked sorghum in a tree hole for a long period occasionally and the cooked sorghum fermented to be wine. Hence, wine was first named “久” (a long period) and then named “酒” (wine).(Lü. J., 2007:128) Another relatively reliable legend was that Yi Di invented wine. The legend appears in some Pre-Qin classics such as Shiben, Master Lü's Spring and Autumn Annals and Strategies of the Warring States Period, and this legend is supported by the archaeological findings of Longshan ancient cultural relics.

In fact, according to records in ancient books, Yellow Emperor discussed how to treat patients with wine with a doctor named Qi Bo in the ages of the three sovereigns. In 1959, complete sets of brewing instruments of pottery, including pottery goblets and double-eared cups, were unearthed. This evidences the fact that ancient Chinese began to brew wine as early as six or seven thousand years ago. Yi Di has been respected as the inventor symbolically by the following generations.

Since the Shang Dynasty, the practice of drinking wine was prevalent. According to the records in The Biographies of the Emperors of Shang, Records of the Grand Historian: "The king Zhou of the Shang Dynasty entertained himself by creating the lake of wine and the forest of meat, making servants walk among the dangled meat pieces and drinking all night long" (SIMA.Q.,1959: 243). Also, there are lines in The Book of Songs about vintage: "Harvest rice in October and brew wine with it" (KONG. Q., 2006:73) and "Your libation has intoxicated me, and your piety has made me satisfied" (KONG. Q., 2006:86), which reflects that vintage with corn and wine-drinking were very popular at that time.

\section{Ancient Wine's Function Related to Religion}

Chinese culture is fragranted with ancient wine. The two most important things were fete and war. Probing into 
the history of Chinese ancient wine, we find that since time immemorial wine has been performing religious and ritual tasks. Before the Xia and Shang Dynasties, whenever a great decision was to be made or a festival concerning a certain god was observed, solemn sacrifice activities would be conducted to pray to the heaven or god for protection and good fortune. It is recorded: "People of the Yin Dynasty paid homage to gods, and so sacrifice took priority over worldly ritual ceremony."(SIMA.Q.,1959:244)The Chinese character “福”carries religious meanings originationg from the Xia and Shang Dynasties. Its original meaning was to offer respectfully a jar of wine in front of gods to pray. Ancients also pour liquid on a bale of thatch, and the liquid infiltrated into the bale, which was much like the god was enjoying the wine. (LIU. X., 2005:266)

\section{Ancient Wine's Function Related to Literature and Art}

Ancient literati were steeped in literary books and had many taboos on etiquette. Wine could liberate literati from the shackles of federal ritual customs transitorily. Rolling out the historical documents of Chinese ancient elegant culture, we smell the strong vinous bouquet coming from between the lines.

Wine was the real reflection of literati's emotional ups and downs. Literati's liking for wine can be classified into three types or three levels. First level was represented by Tao Yuanming, who indulged in wine to the degree of forgetting external and internal affairs, which is supported by his lines- "While picking asters 'neath the Eastern fence, my gaze upon the Southern mountain rests". (TAO.Y., 1979: 108) He tasted the harmony and unity between man and nature. Second level was represented by Li Bai of the Tang Dynasty and Su Shi of the Northern Song Dynasty. They took delight in drinking wine. Through drinking, the drinker got creative inspiration and started their abandoned poetic composing. Third, drinking to forget worries and avoid disasters. Stimulated by wine, literati were brave enough to express their disappointment at political affairs, which was typical of literati of successive generations and very common in the Jin, Song, Yuan and Qing dynasties. "The seven worthies of the bamboo groves" always expressed their pent-up indignation. Ruan Ji had always been drunk for more than one month and Ji Kang's passing out like the oncoming collapse of jade mountains, even his drunken posture displaying sense of beauty.

Wine was not exclusive to males, for some female literati were fond of drinking too. Li Qingzhao, a poetess of the graceful and restrained school, was potatory in daily life, which could be evidenced by her ci-poem, (to the tune of Ru Meng Ling): "Often remembers the Creek Bower at twilight, /Too drunk to tell the way home. /Having had our fill, /Returned at night by boat /And blundered deep into the lotus blooms. /Hurrying through,/ Hurrying through,/ Startled a beach of herons and gulls."(LI. Q., 2006: 57) In a tranquil and mysterious world, the smell of wine and the aroma of flowers freed the peotess from the federal shackles attached to the daughter of an eminent family and made her display her outgoing, vivacious, curious and progressive nature.

Zhuang Zi said, "The drunk are sober" (Zhuang. Z., 2007:254) and Su Shi said, "The intoxicated writer writes well'(SU. S., 2003: 381). Wine-addicted literati created excellent atmosphere with the help of wine. When intoxicated with wine, literati could not only break the rational moral fence but also enhance their desire for and confidence in creation. Superb works were more often than not composed by intoxicated literati, which became the fascinating scroll of Chinese elegant culture.

Studying the relation between wine and elegant culture, we may come to the conclusion that the two added driving force to each other. On the one hand, wine, as the accelerant of elegant culture, advanced the artistic creation. Many ancient literati were fond of drinking, and they liked to poetize when intoxicated, leaving many much-told stories. Du Fu ever wrote a group of poems entitled The Eight Immortal Drinkers, "Zhizhang rode horse like taking a boat when drunk,/ A giddy fall sent him sleeping on the bottom of the well." "Li Bai could turn sweet nectar into verses fine. /Drunk in the capital, he'd lie in shops of wine. /Even imperial summons proudly he'd decline, /Saying immortals could not leave the drink divine." "Legend had it that the Cursive Sage could write well when drunk. /Bareheaded in the presence of noblemen, /He moved his brush fast like the flow of clouds and smoke." (DU. F., 2006: 95-98) Calligraphers often took the advantages of wine to create handwritings. According to ancient books, Wang Xizhi did not write any characters without drinking and each time he drank, he must be drunk. For another instance, Zhang Xu was addicted to wine in legend and was nicknamed "Insane Zhang". When drunken, he often dipped his head into ink and wrote with his head. After waking up, he was surprised by his wonderful calligraphic works but could not repeat the masterpiece." The Four Ancient Poems, the copybook by Zhang Xu when drunken, was considered masterpiece, in which strokes of characters move fast like clouds and smoke. Painters also sought inspiration from wine. Wu Daozi, the saint of painting, was forthright and keen on wine. He ever painted the landscape of the Jialing River at the command of Emperor Minghuang of the Tang Dynasty. He fulfilled the task within only three days with the help of wine.

On the other hand, there were many instruments, poems and articles, paintings, calligraphic works, which, 
related to elegant culture, became the fantastic packaging materials of wine. It is safe to say that "poems were composed with the help of wine, and wine became famous for poems" (Lü. J., 2007:134). The fame of poems helps enhance the reputation of wine. Many poems passed down from ancient times were related to wine. Take the three greatest poets for example. According to statistics, Du Fu altogether left 1,400 poems, 300 of which were related to wine. Li Bai left 1050 poems and 170 poems were related to wine. Bai Juyi left more than 3,000 poems, and those related to wine adds up to more than 900 .

\section{Ancient Wine's Function Related to Entertainment}

The relation between wine and Chinese elegant culture was very close and extensive. Literati were inseparable to wine and meanwhile wine culture involved drinking vessels, drinking customs, and drinking games.

Wine vessels were indispensable to drinking. Ancient people remarked: "No wine vessels, no drinking. Attention should be paid to the sizes of vessels."(Lü. J., 2007:102) Since ancient times, the Chinese have been critical about food and vessels, and drinking vessels involve rites and elegant culture. Dignified, simplistic and elegant bronze wares of the Xia, Shang and Zhou dynasties are typical examples. According to their uses, wine vessels could be classified into three types: wine-hoarding vessels, wine containers, and drinking vessels, which, according to different materials and various shapes, could be subdivided into many sub-types. In classical literature, terms like “觥筹交错” (i.e. drinking vessels and the game tokens mingled together) often appeared. Swordsmen of the Robin Hood type bought wine with large gourd ladle and bowels. Wang Xizhi, the saint of calligraphy, played the game of Qu Shui Liu Shang by the rivers. Li Bai, the god of poetry, wrote a line, "I'd like to dink 300 goblets of wine at one go". Su Dongpo composed such a line: "I poured wine into the river in libation to the shadow of moon." Fan Zhongyan had the words "standing in wind with goblet in hand". Li Qingzhao ever wrote “three goblets and two small cups of wine”. “觥” “樽” “杯” “盏” are all drinking vessels, the names of which suggested the differences between the drinkers and the wine customs of their respective ages. For instance, ancient people lapped water from wine pool and swordsmen of the Robin Hood type boozed wine with gourd ladles and bowels, and literati drank with goblets and cups.

Drinking games were one unique feature of Chinese wine culture. Playing drinking games was a very useful way to enhance enjoyment. Drinking games could be categorized into elegant games and popular games. When elegant drinking games were played, the drinkers should improvise poems and articles to show off his literary talents. Popular drinking games referred to dice-tossing, lot-drawing, finger-guessing, number-guessing, etc. All the games were helpful to liven up the atmosphere at the feast.

Drinking games were very common in daily life, and they were reflected in classic literature. For instance, in the forty chapter of A Dream of Red Chamber, Yuan Yang was in charge of the drinking games at the banquet, which was the situation of playing drinking games at upper-class banquets in the Qing Dynasty. The drinking game described in Strange Stories from a Scholar's Studio might serve to be an example which suits both refined and popular tastes:

Several goblets of wine have been drunken, then someone started a game by using a Chinese character: "The Chinese character ' $⿴ 囗 十$ 'is all-sidedly enclosed with a Chinese character '十' in the heart; push the Chinese character '十'upwards, then another Chinese character of '古' is formed, so I can be excused from a goblet of wine." A second person picked up: "The Chinese character '回' is all-sidedly enclosed with a Chinese character ' 口'in the heart; push the Chinese character ' $口$ 'upwards, then another Chinese character of '吕' is formed, so I can be excused from a goblet of wine." Then a third person continued: "The Chinese character '图' is all-sidedly enclosed with a Chinese character '令' in the heart; push the Chinese character '令'upwards, then another Chinese character of '含' is formed, so I can be excused from a goblet of wine." Then a fourth person continued the game, “The Chinese character '困' is all-sidedly enclosed with a Chinese character “木' in the heart; push the Chinese character '木' upwards, then another Chinese character of '杏' is formed, so I can be excused from a goblet of wine."Finally, it was Zhan's turn to carry on the game, but he failed. The others laughed, "Now that you have failed, you should drink a goblet of wine."A goblet of wine was passed to him, when Zhan continued in a hurry, "Alas! I've got it. The Chinese character '曰' is all-sidedly enclosed with a Chinese character '一'in the heart, ..."The others laughed again, challengling, "Then what is formed?"Zhan had no choice but to drink the goblet of wine, laughing, "Push the Chinese character '—' upwards, then no Chinese character is formed, so I have to drink up this goblet of wine!"(PU, S., 2004:317)

Drinking games embody the hospitability of ancient people, and they are also the combination of the art of drinking and wisdom. 


\section{Conclusion}

In short, in ancient China wine culture experienced two important periods. In the first period, wine performed the function of religion (namely sacrifice), closely related to imperial cerimony. In the second period, it performed the function of literature, art and entertainment after its introduction into the countryside by aristocracies and high officials. This period began in the Wei and Jin Dynasties and became popular in the Tang and Song Dynasties. Chinese unique wine culture came into existence when the functions performed by wine in the two periods were combined. As a special culture form, wine culture has not only permeateted intoChinese people's material life but also exerted great influence on people's sipiritual life.

\section{References}

Ban, G. (2007). The History of the Han Dynasty (pp. 394-395). Beijing: Zhonghua Book Company.

Du, F. (2006). A Collection of Du Fu's Works (pp. 95-98). Beijing: Zhonghua Book Company.

Kong, Q. (2006). The Book of Songs (p. 73). Beijing: Zhonghua Book Company.

Li, Q. (2006). A Selection of LI Qing-zhao’s Poems (p. 57). Beijing: Zhonghua Book Company.

Liu, X. (2005). Strategies of theWarring States (p. 266). Jinan: Qilu Publishing House.

Lü, J. (2007). Banquet Etiquette of Ancient China (p. 128). Beijing: Beijing Institute of Technology Press.

$\mathrm{Pu}, \mathrm{S}$. (2004). Strange Stories from a Scholar's Studio (p. 317). Tianjin: Tianjin Ancient Books Publishing House.

Ruan, Y. (1980). The Thirteen Classics. Beijing: Zhonghua Book Company.

Sima. Q. (1959). Records of the Historian (p. 243). Beijing: Zhonghua Book Company.

Song, Z. (1985). Shiben (p. 117). Beijing: Zhonghua Book Company.

Su, S. (2003). A Collection of SU SHI's Aritcles and Poems (p. 381). Beijing: Zhonghua Book Company.

Tao, Y. (1979). A Collection of Tao Yuan-ming's Works (p. 108). Beijing: Zhonghua Book Company.

Xu, S. (1963). Word and Expression. Beijing: Zhonghua Book Company.

Zhuang, Z. (2007). Zhuang Zi (p. 254). Beijing: Zhonghua Book Company. 